\title{
天然カドミウムの $\boldsymbol{a}$ および ${ }^{3} \mathrm{He}$ 照射による ${ }^{11} \mathrm{In}$ の生成
}

\author{
中村由美, 中原弘道, 村上悠紀雄* \\ 東京都立大学理学部 158 東京都世田谷区深沢2-1-1 \\ 北里大学衛生学部 228 相模原市北里1-15 \\ 1979年 6 月15日受理
}

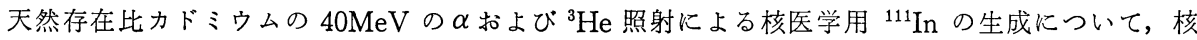
反応の励起曲線, 厚いターダット収率を求め, 放射化学的純度を考虑して最適照射条件を比較検討 した。收率, 純度の点から ${ }^{111} \mathrm{In} の$ 生成は ${ }^{3} \mathrm{He}$ 照射がすぐれていることがわかった。最適条件は, ${ }^{3} \mathrm{He}$ 粒子の入射エネルギー $40 \mathrm{MeV}$ ，ターゲット厚 $280 \mathrm{mg} / \mathrm{cm}^{2}$ で，収率は $270 \mu \mathrm{Ci} / \mu \mathrm{A} \cdot \mathrm{h}$ となり， 副生成核種 $\left({ }^{114 m} \mathrm{In},{ }^{109} \mathrm{In},{ }^{110} \mathrm{In}\right)$ の混入があるが照射終了後 54 時間経たとき ${ }^{111} \mathrm{In}$ の放射化学的純度 が最も高くなる。臭化水素一イソプロピルエーテル系での溶媒抽出でターゲットより分離し, 陰イ オン交換樹脂カラムを用いて Sn を分離すると高純度のキャリアフリー ${ }^{111} \mathrm{In}$ の分離ができた。
\end{abstract}

Key Words: indium-111, cadmium target, alpha reaction, helium-3 reaction, chemical separation, excitation function, thick-target yield

\section{1. 緒言}

現在核医学に抢いてインジウムの放射性同位体が腫 瘍の診断, 骨のスキャニング，臓器の機能検査等に利 用されている。この利用に適した核種は，半減期1.93 時間の ${ }^{113 m} \mathrm{In}$ と半減期 2.81 日の ${ }^{111} \mathrm{In}$ である ${ }^{1)}$ 。短寿 命核種である ${ }^{113 m} \mathrm{In}$ は半減期 115 日の ${ }^{113} \mathrm{Sn}$ の娘核種 としてミルキングで得られるが，スキャニングとして は $4 \sim 8$ 時間程度しか使用できない2)。これに対して ${ }^{111} \mathrm{In}$ は半減期が長いため長時間にわたりスキャニング に使用できる利点がある。また， ${ }^{111} \mathrm{In}$ は注涪 100\%の $\mathrm{EC}$ 壊変で ${ }^{111} \mathrm{Cd}$ の励起状態に崩壊し, 低エネルギー の $\gamma$ 線 $[171 \mathrm{keV}(89 \%), 245 \mathrm{keV}(94 \%)]$ を 2 個放 出して基底状態に落ちる。このため非常に高い検出効 率で測定できる，また，EC 壊変であるため放射性医 薬品として患者に投与するさい，その吸収線量が低い という利点がある。

現在 ${ }^{111} \mathrm{In}$ は銀をターゲットとして ${ }^{109} \mathrm{Ag}(\alpha, 2 n)$ ${ }^{111} \mathrm{In}$ 反応 ${ }^{3)}$ ，カドミウムの濃縮ターゲットを用いて ${ }^{111} \mathrm{Cd}(p, n)^{111} \mathrm{In},{ }^{112} \mathrm{Cd}(p, 2 n){ }^{111} \mathrm{In}$ 反応4) などでつくら れている。これに対して，天然カドミウムに ${ }^{3} \mathrm{He}$ 照射 を行った実験データがないことから，天然カドミウム をターゲットとして， $\alpha,{ }^{3} \mathrm{He}$ 照射を比較検討すること にした。また，カドミウムの 8 種の同位体から扣こる $\alpha$ 照射による $x n$ 反応，pxn 反応，また ${ }^{3} \mathrm{He}$ 照射に よる $x n$ 反応， $p x n$ 反応について詳しいデータを得る といら目的でおこなった。これらの実験より，励起関 数, 厚いターゲット収率曲線を求め, その結果から
${ }^{111} \mathrm{In}$ の最適照射条件を求めた。さらに，キャリアフリ 一で ${ }^{111} \mathrm{In}$ をらる放射化学的分離法などを研究した。

\section{2. 実 験}

$2 \cdot 1$ ターゲットの作成

ターゲットの作成には電着法を用いた。直径 $3.1 \mathrm{~cm}$, 高さ $7 \mathrm{~cm}$ の塩化ビニル製の円筒を電解セルとし，陽 極に直径 $0.3 \mathrm{~mm}$ の白金線を用い，陰極のニッケル板 $(50 \mu \mathrm{m})$ 上に天然カドミウムを電着した。電着溶液 の組成は, $\mathrm{Cd}\left(\mathrm{BF}_{4}\right)_{2} 240 \mathrm{~g} / l, \mathrm{NH}_{4} \mathrm{BF}_{4} 60 \mathrm{~g} / l, \mathrm{H}_{3} \mathrm{~B}$ $\mathrm{O}_{3} 27 \mathrm{~g} / l$, 甘草 $1.1 \mathrm{~g} / l$ であり ${ }^{5}$, 電着は $20^{\circ} \mathrm{C}, \mathrm{pH}$ 3〜3. 5, 電流密度 $40 \sim 50 \mathrm{~mA} / \mathrm{cm}^{2}$, 電圧 $3 \sim 5 \mathrm{~V}$ でお こなった。電着時間 $10 〜 20$ 分で $20 \sim 30 \mathrm{mg} / \mathrm{cm}^{2}$ 厚のカ ドミウムフォイルが得られた。これは，ピンセットで ニッケル板から容易にはがすことができ，セルフサポ 一トのカドミウムフォイルを作成できた。陰極に用い たニッケル板は表面に傷のないなめらかでないと均一 なカドミウムフォイルはつくれないため, 希塩酸で洗 浄後アセトンでよごれをふきとり逆電圧で数秒電流を 通じたのち，電着液を取りかえて洗浄し，上記のごと く電着を行った。カドミウムフォイルは水洗乾燥後, 重量を測定し，照射エネルギーに応じて10〜15枚をス タックとして照射に用いた。

\section{$2 \cdot 2$ 照射}

照射は理化学研究所サイクロトロンの第 2 コース にて，加速エネルギー $40 \mathrm{MeV}, 27 \mathrm{MeV}$ の $\alpha$ 粒子, ${ }^{3} \mathrm{He}$ 粒子を用いて行った。照射条件は，長寿命核種を生成 
する場合はビーム電流 $0.3 \sim 0.5 \mu \mathrm{A}$ で 30 分間照射し， 短寿命核種を生成する場合は $0.2 \mu \mathrm{A} て ゙ 2 \sim 5$ 分間照射 を行った。ビーム電流はファラディカップを電流積算 計に接続して測定した。また，ターゲット表面でのビ 一ムの広がりは，Qマグネットとスリットなどにより 約 $10 \times 10 \mathrm{~mm}$ に調整した。ターゲット面などからの二 次電子の損失は約 $8 \%$ とした。

\section{$2 \cdot 3$ 測定}

反応生成物からの $\gamma$ 線は, $40 \mathrm{cc} \mathrm{Ge}(\mathrm{Li})$ 検出器 -2048 チャネル波高分析器で測定した。検出効率はIAEA標 準線源を用いて定立体角法で求めた。核種の同定は, 放出される だ)。また ${ }^{111} \mathrm{In}$ の親核種である ${ }^{111} \mathrm{Sn}$ は半減期35分で, 放出 $r$ 線は強度が弱く $760 \mathrm{keV}(1.1 \%), 1150 \mathrm{keV}(1.8$ \%) と測定がむずかしかったので，照射直後に Sn の 迅速分離を行って In 核種からの妨害を除いて測定し だ)。すなわち，照射したターゲットを少量の $11 N$ 臭 化水素酸に溶解し, $\mathrm{Sn}^{4+}$ キャリア $20 \mathrm{mg}$ を加兄, $1: 1$ $\mathrm{H}_{2} \mathrm{SO}_{4} 10 \mathrm{ml}$, 臭素水 $1 \mathrm{ml}$ 加えて $\mathrm{H}_{2} \mathrm{SO}_{4}$ の白煙が出 てくるまで蒸留した。蒸留物は $0.2 \mathrm{~N} \mathrm{HCl}$ 溶液中に捕 集し，新たに調製した $49.14 \mathrm{mg} / \mathrm{ml} \mathrm{Na}_{2} \mathrm{SO}_{3}$ 溶液を加 えて還元してから， $\mathrm{NaOH}$ で水酸化物の沈殿をつく り測定した。

\section{$2 \cdot 4$ 化学分離}

インジゥムのキャリアフリー分離に対して, $\mathrm{Fe}$ (III) の水酸化物による共沈法, 臭化水素酸一イソプロピル エーテル系による溶媒抽出法"), 陽イオン交換樹脂 (Dowex1）によるイオン交換法 ${ }^{10)}$ など種々の方法を検 討した結果,つぎの方法が最も適当であった。照射した カドミウムターゲット(例 $\mathrm{Cd} 200 \mathrm{mg}$ )を $5 \mathrm{ml} 11 \mathrm{~N}$ HBrに溶解し, $5.5 \mathrm{NHBr}$ 溶液にしてィソプロピルエー テル $15 \mathrm{ml} て ゙$ In を抽出した。このとき，放射性スズも 抽出されるので, イソプロピルェーテルから放射性イ ンジゥムを水 $10 \mathrm{mll}$ 逆抽出した。これを $0.5 \mathrm{~N} \mathrm{HCl}$ 溶 液にして，陰イオン交換樹脂カラム(Dowex 1X8, 200 ２50mesh, $0.5 \mathrm{~cm}^{2} \times 10 \mathrm{~cm}$ ) 飞流速 $0.5 \mathrm{ml} / \mathrm{min}$ で通す と, 通過液に放射性インジゥムはみられた。 ${ }^{111} \mathrm{In}$ の収 率は80〜90\%であった。

\section{3. 結果および考察}

$3 \cdot 1$ 生成断面積および厚いターゲット収率

測定された核種（Table 1 参照）の生成断面積を入 射ェネルギーの関数として， $\alpha$ 反応， ${ }^{3} \mathrm{He}$ 反応につい
てそれぞれの励起曲線を求めた。 $\alpha,{ }^{3} \mathrm{He}$ 反応でできる 比較的半減期の長い 8 核種について Figs. 1, 2 亿示し た。各フォイルに入射する粒子のエネルギーは，Williamson らの計算した飛程一エネルギー関係の值を用 いて計算した ${ }^{11}$ 。 ${ }^{109} \mathrm{In},{ }^{111} \mathrm{In}$ の生成断面積は，それぞ れの親核種である ${ }^{109} \mathrm{Sn}$ (半減期 18 分), ${ }^{111} \mathrm{Sn}$ (半減期 35分）から生成する ${ }^{109} \mathrm{In},{ }^{111} \mathrm{In}$ との和として求めた。 これらの核反応は反応のしきい值とクーロン障壁お。 よびターゲット核種の存在比一 ${ }^{106} \mathrm{Cd}(1.22 \%),{ }^{108} \mathrm{Cd}$ (0.88\%), ${ }^{110} \mathrm{Cd}(12.39 \%),{ }^{111} \mathrm{Cd}(12.75 \%),{ }^{112} \mathrm{Cd}$ (24.07\%), ${ }^{113} \mathrm{Cd}(12.36 \%),{ }^{114} \mathrm{Cd}(28.86 \%),{ }^{116} \mathrm{Cd}$ (7.58\%)一をもとに推定した (Table 2 参照)。

Table 1

\begin{tabular}{c|c|c|c}
\hline Nuclides & $\begin{array}{c}\gamma \text {-ray } \\
\text { energy } \\
(\mathrm{MeV})\end{array}$ & $\begin{array}{c}\text { Intensity } \\
(\%)\end{array}$ & Half-life \\
\hline${ }^{111} \mathrm{In}$ & 0.171 & 89.0 & $2.81 \mathrm{~d}$ \\
${ }^{109} \mathrm{In}$ & 0.203 & 72.1 & $4.3 \mathrm{~h}$ \\
${ }^{110} \mathrm{In}$ & 0.707 & 32.0 & $4.9 \mathrm{~h}$ \\
${ }^{114 m} \mathrm{In}$ & 0.558 & 4.65 & $50 \mathrm{~d}$ \\
${ }^{110} \mathrm{Sn}$ & 0.280 & 95.0 & $4.0 \mathrm{~h}$ \\
${ }^{113} \mathrm{Sn}$ & 0.393 & 62.8 & $115 \mathrm{~d}$ \\
${ }^{117 m} \mathrm{Sn}$ & 0.158 & 87.0 & $14 \mathrm{~d}$ \\
${ }^{115} \mathrm{Cd}$ & 0.525 & 26.5 & $53.5 \mathrm{~h}$ \\
\hline
\end{tabular}

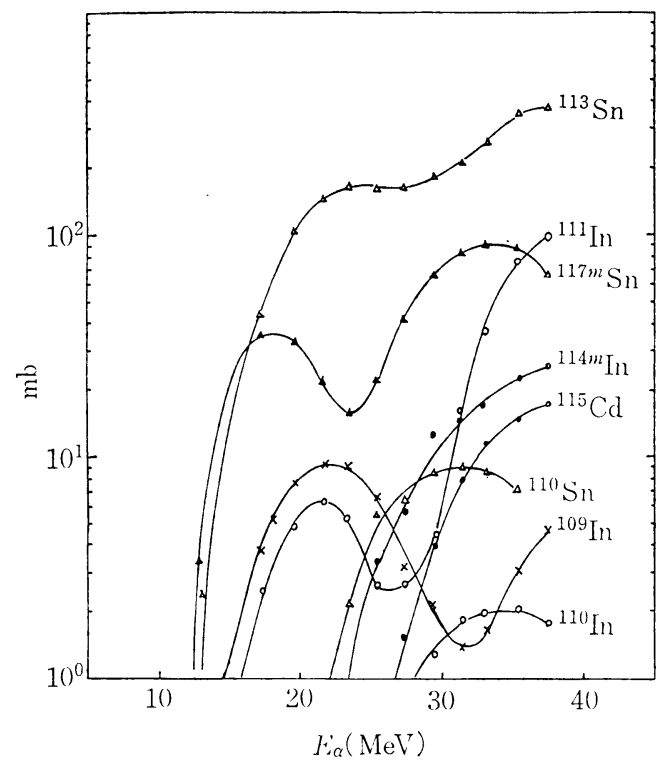

Fig. 1 Formation cross sections of ${ }^{109} \mathrm{In},{ }^{111} \mathrm{In}$, ${ }^{110} \mathrm{In},{ }^{114 m} \mathrm{In},{ }^{115} \mathrm{Cd},{ }^{109} \mathrm{Sn},{ }^{113} \mathrm{Sn}$, and ${ }^{117 m} \mathrm{Sn}$ produced by alpha bombardment on natural cadmium. 
Table 2

\begin{tabular}{|c|c|c|c|c|c|c|c|}
\hline \multicolumn{2}{|c|}{ Products } & \multicolumn{3}{|c|}{${ }^{3} \mathrm{He}$-bombardment } & \multicolumn{3}{|c|}{$\alpha$-bombardment } \\
\hline nuclides & H.L. & $\begin{array}{l}\text { Target } \mathrm{Cd} \\
\text { nuclides }\end{array}$ & $\begin{array}{l}\text { Emitted } \\
\text { particles }\end{array}$ & $Q$ value & $\begin{array}{l}\text { Target Cd } \\
\text { nuclides }\end{array}$ & $\begin{array}{l}\text { Emitted } \\
\text { particles }\end{array}$ & $Q$ value \\
\hline \multirow[t]{2}{*}{${ }^{109} \mathrm{In}$} & $4.3 \mathrm{~h}$ & 108 & $p n$ & -3.15 & 106 & $p$ & -6.64 \\
\hline & & 110 & $p 3 n$ & -20.28 & 108 & $p 2 n$ & -23.72 \\
\hline \multirow[t]{2}{*}{${ }^{109} \mathrm{Sn}$} & $18 \mathrm{~m}$ & 108 & $2 n$ & -9.00 & 106 & $n$ & -10.16 \\
\hline & & 110 & $4 n$ & -26.70 & 108 & $3 n$ & -28.42 \\
\hline \multirow[t]{2}{*}{${ }^{110} \mathrm{In}$} & $4.9 \mathrm{~h}$ & 110 & $p 2 n$ & -12.43 & 108 & $p n$ & -15.77 \\
\hline & & 111 & $p 3 n$ & -19.41 & 110 & $p 3 n$ & -23.15 \\
\hline \multirow[t]{4}{*}{${ }^{111}$ In } & $2.81 \mathrm{~d}$ & 110 & $p n$ & -2.67 & 108 & $p$ & -5.91 \\
\hline & & 111 & $p 2 n$ & -9.80 & 110 & $p 3 n$ & -23.15 \\
\hline & & 112 & $p 3 n$ & -19.45 & & & \\
\hline & & 113 & $p 4 n$ & -25.84 & & & \\
\hline \multirow[t]{3}{*}{${ }^{111} \mathrm{Sn}$} & $35 \mathrm{~m}$ & 110 & $2 n$ & -5.95 & 108 & $n$ & -9.27 \\
\hline & & 111 & $3 n$ & -12.93 & 110 & $3 n$ & -26.53 \\
\hline & & 112 & $4 n$ & -22.91 & & & \\
\hline \multirow[t]{3}{*}{${ }^{114 m} \mathrm{In}$} & $50 \mathrm{~d}$ & 112 & $p$ & -1.10 & 111 & $p$ & -5.53 \\
\hline & & 113 & $p n$ & -10.10 & 112 & $p n$ & -14.93 \\
\hline & & 114 & $p 2 n$ & -24.20 & โ13 & $p^{2 n}$ & -21.47 \\
\hline
\end{tabular}

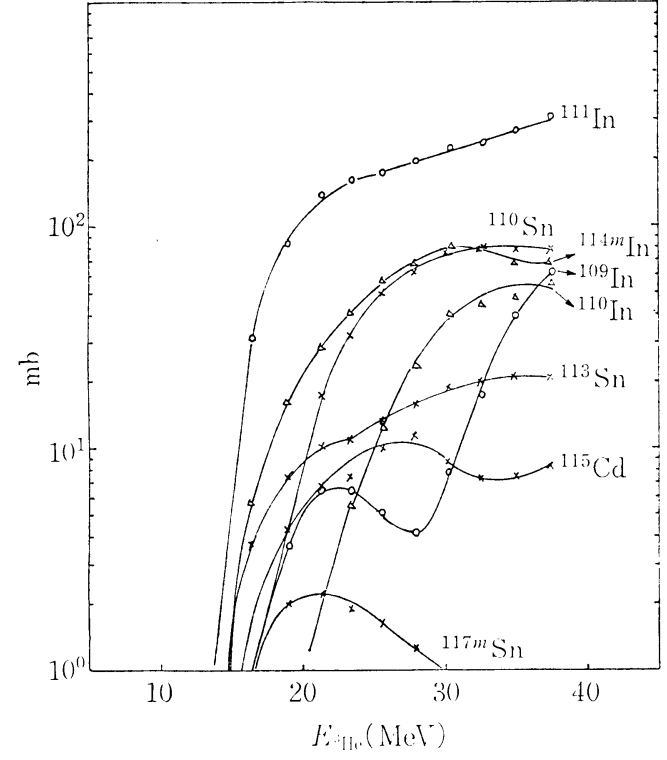

Fig. 2 Formation cross sections of ${ }^{111} \mathrm{In},{ }^{110} \mathrm{Sn}$, ${ }^{114 m} \mathrm{In},{ }^{109} \mathrm{In},{ }^{110} \mathrm{In},{ }^{113} \mathrm{Sn},{ }^{115} \mathrm{Cd},{ }^{117 m} \mathrm{Sn}$, produced by helium-3 bombardment on natural cadmium.

厚いターゲット収率は，各ターゲットにおける各生 成核種の生成量を $\mu \mathrm{Ci} / \mu \mathrm{A} \cdot \mathrm{h}$ の単位に換算し，低ェネ ルギー側のターゲットから順次加算する常法にしたが って求めた。Fig. 3 に示すように, ${ }^{111} \mathrm{In}$ の厚いターゲ

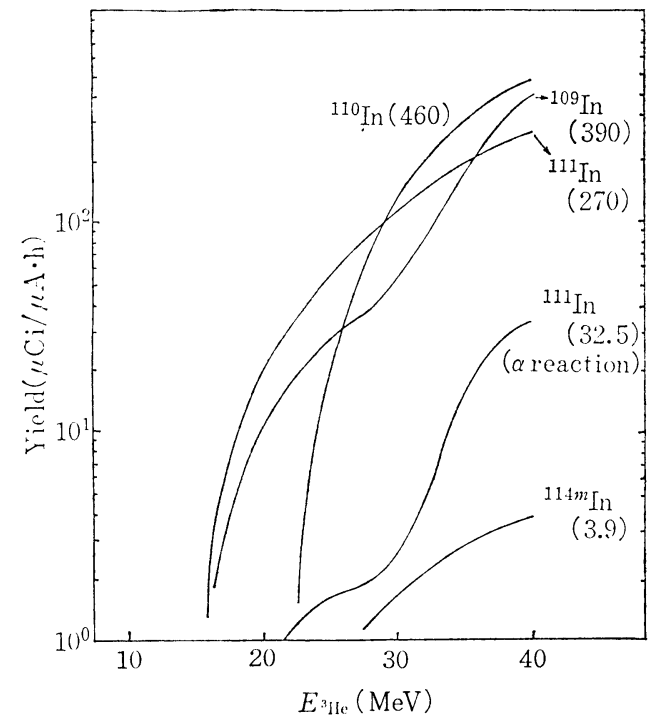

Fig. 3 Thick-target yield curves of ${ }^{109} \mathrm{In},{ }^{110} \mathrm{In}$, ${ }^{111} \mathrm{In}$, and ${ }^{114 m} \mathrm{In}$ observed for the helium -3 reactions on natural cadmium. The numbers in the parentheses given after the nuclide are the thick-target yields expected for the $40 \mathrm{MeV}$ incident energy.

ットに対する収率は, $40 \mathrm{MeV}$ の $\alpha$ 照射では $32 \mu \mathrm{Ci} / \mu \mathrm{A}$ •h, ${ }^{3} \mathrm{He}$ 照射では $270 \mu \mathrm{Ci} / \mu \mathrm{A} \cdot \mathrm{h}$ であった。 $\alpha$ 照射の 場合の収率が， ${ }^{3} \mathrm{He}$ 照射に比べて小さいのは ${ }^{108} \mathrm{Cd} の$ 
天然存在比が $0.88 \%$ と小さいことによる。収率の点か ら $\alpha$ 反応は ${ }^{111}$ In 9 製法として実用的でないことがわ かったので， ${ }^{3} \mathrm{He}$ 反応で生成する In の放射性同位体の みをFig. 3 に示し，以下考察を行った。

\section{$3 \cdot 2$ 最適照射条件之放射化学的純度}

In の化学分離精製後, ${ }^{111} \mathrm{In}$ の放射性同位体として 存在するのは, ${ }^{109} \mathrm{In}$ (半減期 4.3 時間), ${ }^{110} \mathrm{In}$ (半減期 4. 9 時間), ${ }^{114 m} \mathrm{In}$ (半減期 50 日) と ${ }^{110} \mathrm{Sn}$ (半減期 4.0 時間) の娘核種である ${ }^{110} \mathrm{In}$ (半減期 67 分) である。 ${ }^{111} \mathrm{In}$ に対して半減期の短い ${ }^{109} \mathrm{In},{ }^{110} \mathrm{In}$ は冷却時間を 長くすることによって混入をさけることがでさる。よ って， ${ }^{114 m} \operatorname{In}$ の生成を扣さえるための照射条件を求める ことにした。各入射ェネルギーにおける ${ }^{111} \mathrm{In} と^{114 m} \mathrm{In}$ の収率の比を計算すると, 加速エネルギー $40 \mathrm{MeV}$ ま での範囲では, ${ }^{114 m} \mathrm{In}$ の混入率が最も小さくなるのは $40 \mathrm{MeV}$ の場合であり, このときの ${ }^{111} \mathrm{In}$ の生成量は $270 \mu \mathrm{Ci} / \mu \mathrm{A} \cdot \mathrm{h},{ }^{114 m} \mathrm{In}$ の生成量は $3.9 \mu \mathrm{Ci} / \mu \mathrm{A} \cdot \mathrm{h}$ であ るから $1.44 \%$ の ${ }^{114 m} \mathrm{In}$ 混入率である。本実験では $40 \mathrm{MeV}$ までしか照射できなかったが，励起曲線など から推察すると， $50 〜 60 \mathrm{MeV}$ までの加速が有効と考 えられる。

Fig. 4 は副生成核種 $\left({ }^{110} \mathrm{In}+{ }^{109} \mathrm{In}+{ }^{114 m} \mathrm{In}\right) /{ }^{111} \mathrm{In} の$ 照射終了時からの経過時間に対する変化を示した。 ${ }^{111}$ In の放射化学的純度は, ${ }^{109} \mathrm{In}$ と ${ }^{110} \mathrm{In}$ の減衰とと むに向上するが， ${ }^{114 m} \operatorname{In} の$ 混入が主となり，照射終了

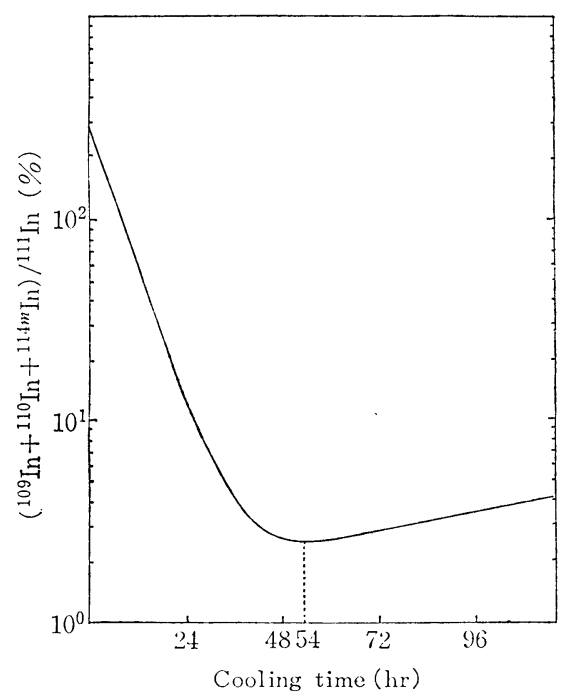

Fig. 4 Relation between the cooling-time and the radiochemical purity of ${ }^{111} \mathrm{In}$ produced by ${ }^{3} \mathrm{He}$ reaction.

後 54 時間以後またわるくなる。よって患者への投与 と検査の終了時間のめやすとしてこの時間を用いると よい。

\section{4. ${ }^{111}$ In の他の製法との比較}

Table 1 亿示すように, 天然カドミウムにプロトン を照射した場合， ${ }^{111} \mathrm{In}$ は ${ }^{111} \mathrm{Cd}(p, n),{ }^{112} \mathrm{Cd}(p, 2 n)$ 反

Table 3 Comparison with other methods for the production of ${ }^{111} \mathrm{In}^{*}$

\begin{tabular}{|c|c|c|c|c|c|c|}
\hline Target & Reaction & \begin{tabular}{|l|}
$\begin{array}{l}\text { Incident } \\
\text { beam energy } \\
(\mathrm{MeV})\end{array}$ \\
\end{tabular} & $\begin{array}{l}\text { Thick-target } \\
\text { yield } \\
(\mu \mathrm{Ci} / \mu \mathrm{A} \cdot \mathrm{h})\end{array}$ & Purification method & Impurities & Reference \\
\hline $\begin{array}{c}{ }^{110} \mathrm{Cd} \\
(\text { enrich Cd) }\end{array}$ & ${ }^{110} \mathrm{Cd}(d, n)$ & 15 & 18 & $\begin{array}{l}\mathrm{Fe}\left(\mathrm{OH}_{3}\right) \\
\text { coprecipitation }\end{array}$ & ${ }^{109} \mathrm{In},{ }^{115} \mathrm{In}$ & (12) \\
\hline$\underset{\text { (natural) }}{\mathrm{Cd}}$ & ${ }^{111} \mathrm{Cd}(p, n)$ & 15 & 140 & $\begin{array}{l}\text { Solvent } \\
\text { extraction }\end{array}$ & ${ }^{114 m} \operatorname{In}$ & (13) \\
\hline $\begin{array}{c}{ }^{111} \mathrm{Cd} \\
(\text { enrich Cd) }\end{array}$ & ${ }^{111} \mathrm{Cd}(p, n)$ & 16 & 515 & $\begin{array}{l}\text { Solvent } \\
\text { extraction }\end{array}$ & ${ }^{114 m} \mathrm{In}$ & (4) \\
\hline$\left(\begin{array}{l}{ }^{109} \mathrm{Ag} \\
(\text { enrich Cd) }\end{array}\right.$ & ${ }^{109} \mathrm{Ag}(\alpha, 2 n)$ & 30 & 200 & Ion exchange & ${ }^{109} \mathrm{In}$ & (3) \\
\hline$\underset{\text { (natural) }}{\mathrm{Cd}}$ & $\begin{array}{l}{ }^{110} \mathrm{Cd}\left({ }^{3} \mathrm{He}, p n\right) \\
{ }^{111} \mathrm{Cd}\left({ }^{3} \mathrm{He}, p 2 n\right) \\
{ }^{112} \mathrm{Cd}\left({ }^{3} \mathrm{He}, p 3 n\right) \\
{ }^{110} \mathrm{Cd}\left({ }^{3} \mathrm{He}, 2 n\right) * * \\
{ }^{111} \mathrm{Cd}\left({ }^{3} \mathrm{He}, 3 n\right) * *\end{array}$ & 40 & 270 & $\begin{array}{l}\text { Solvent } \\
\text { extraction } \\
\text { Ion exchange }\end{array}$ & $\begin{array}{l}{ }^{109} \mathrm{In} \\
{ }^{110} \mathrm{In} \\
{ }^{114 m} \mathrm{In}\end{array}$ & present work \\
\hline
\end{tabular}

* Some of the data are taken from ref. (14).

** ${ }^{111} \mathrm{In}$ is produced through EC decay of ${ }^{111} \mathrm{Sn}$. 
応で生成する。同時に, ${ }^{114} \mathrm{Cd}(p, n)$ 反応で ${ }^{114 m} \mathrm{In}$ も 生成される。天然カドミウム中の ${ }^{114} \mathrm{Cd}$ の存在比は $28.86 \%$ あるため, $15 \mathrm{MeV}$ のプロトンを照射したさ い照射終了時 ${ }^{114 m} \mathrm{In}$ の混入は $3 \%$ ある ${ }^{13)} 。{ }^{111} \mathrm{Cd}$ の 濃縮ターゲット $\left({ }^{111} \mathrm{Cd} 96.5 \%,{ }^{112} \mathrm{Cd} 1.84 \%,{ }^{114} \mathrm{Cd}\right.$ $0.59 \%$ ) を用いると， $16 \mathrm{MeV}$ のプロトンを照射した 場合の照射終了時 ${ }^{114 m} \mathrm{In}$ の混入は $0.012 \pm 0.002 \%$ に 減少させることができる4)。しかし， ${ }^{111} \mathrm{Cd}$ の濃縮タ 一ゲットは高価である。重陽子照射による ${ }^{110} \mathrm{Cd}(d, n)$ 反応による ${ }^{111}$ In の厚いターゲット収率は非常に低 $W^{12)}$ 。銀に $\alpha$ 粒子を照射した場合の ${ }^{111}$ In の生成量は, 天然カドミウムに ${ }^{3} \mathrm{He}$ を照射した場合とかわらず，副 生成核種も半減期が短いため放射化学的純度が高く, カドミウムより銀の価格が高いという点を除けばよい 製法である。

\section{4. 結 び}

天然カドミウムのターゲットとしての電着条件を明 らかにし，これを用い $\alpha,{ }^{3} \mathrm{He}$ 照射を行い ${ }^{111} \mathrm{In}$ の生成 に関する最適生成条件を決めた。両反応の比較より, ${ }^{3} \mathrm{He}$ 照射のほうが製法としてすぐれていることがわか った。カドミウム $280 \mathrm{mg} / \mathrm{cm}^{2}$ に $40 \mathrm{MeV}$ の ${ }^{3} \mathrm{He}$ 照射を 行うことにより $270 \mu \mathrm{Ci} / \mu \mathrm{A} \cdot \mathrm{h}$ の ${ }^{111} \mathrm{In}$ が得られる。 キャリアフリー分離を执こならには， ${ }^{111} \mathrm{Sn}$ から生成 する ${ }^{111}$ In が最大となる照射終了後約 4 時間以後に, $6 \mathrm{NHBr}$ ーイソプロピルエーテル系による溶媒抽出と, 陰イオン交換樹脂 (Dowex 1X8) によるイオン交換 法を用いるのが最も適当である。化学的収率は80〜90 \%であり Cd, Sn の混入はなかった。また ${ }^{111} \mathrm{In} の$ 放 射化学的純度から考学ると，照射終了後54時間のとき In の他核種からの妨害が最も小さくなる。

\section{文献}

1) C.M. Lederer, J.M. Hollander and I. Perlman: 'Table of Isotopes', John Willey, New York (1967)

2) V.I. Levin, M.D. Kozlova, A.B. Malivin, A.S. Sevastyanona, N.V. Kurankov, V.T. Kharlamov and A.F. Guskov: Int. J. appl. Radiat. Isotopes, 28, 667 (1977)

3) M.L. Thakur and A.D. Nunn: Int. J. appl. Radiat. Isotopes, 23, 139 (1972)

4) L.C. Brown and A.L. Beets: ibid., 23, 57 (1972)

5）めっき技術便覧編集委員会編，めっき技術便覧， p.187，日刊工業新聞社 (1971)

6) T. Nozaki: Private communication

7) Atomic Data and Nuclear Data Table, 13, (1974)

8) J.W. Winchester: Nuclear Science Series Report, NAS-NS-3023, 53 (1960)

9) D.N. Sunderman, I.B. Ackermann and W.W. Meinke: Anal. Chem., 31, 41 (1959)

10) Frederick Nelson, Richard M. Rush and Kurt A. Kraus: J. Am. Chem. Soc., 82, 339 (1960)

11) C.F. Williamson, J.P. Boujot and J. Picard: Saclay Report CEA-R 3042 (1966)

12) I.J. Gruverman and P. Kruger: Int. J. appl. Radiat. Isotopes, 5, 21 (1959)

13) J.R. Dahl and R.S. Tilbury: ibid., 23, 431 (1972)

14) M.L. Thakur: ibid., 28, 183 (1977) 


\title{
Abstract
}

\section{Formation of Indium-111 in Alpha and Helium-3 Bombardment of Natural Cadmium}

\author{
Yumi NAKAMURA, Hiromichi NAKahaRA and Yukio MuRAKAMI* \\ Department of Chemistry, Faculty of Science, Tokyo Metropolitan University \\ Fukazawa, Setagaya-ku, Tokyo 158, Japan \\ *School of Hygenic Science, Kitasato University \\ 15, Kitasato 1, Sagamihara-shi 228, Japan
}

Formation cross sections and thick-target yields were studied in detail for alpha reactions and helium-3 reactions of natural cadmium in the energy range $10-40 \mathrm{MeV}$ in order to determine the optimum condition for the production of medical use ${ }^{111} \mathrm{In}$. The helium-3 reactions were found to give higher ${ }^{111}$ In yield; namely, at the optimum helium-3 particle energy of 40 $\mathrm{MeV}$ and with the cadmium foil of $280 \mathrm{mg} / \mathrm{cm}^{2}$ thickness the amount of ${ }^{111} \mathrm{In}$ produced was $270 \mu \mathrm{Ci} / \mu \mathrm{A} \cdot \mathrm{h}$. A cooling-time of 54 hours was required for the best radiochemical purity. The extraction of $\mathrm{HBr}$-isopropyl ether followed by the anion exchange method was found to be the best chemical method for the carrier-free indium-111 separation.

(Received June 15, 1979) 